\title{
PENERAPAN MODEL PEMBELAJARAN GROUP INVESTIGATION UNTUK MENINGKATKAN HASIL BELAJAR GEOGRAFI SISWA KELAS X IPSI SMA NEGERI 1 KABAWO PADA MATERI POKOK MENGANALISIS HIDROSFER
}

\author{
Risna $^{1}$, Surdin $^{2}$ \\ ${ }^{1}$ Alumni Pendidikan Geografi FKIP UHO \\ ${ }^{2}$ Dosen Pendidikan Geografi FKIP UHO
}

\begin{abstract}
Abstrak : Tujuan dalam penelitian ini adalah untuk mendapatkan data dan gambaran tentang: 1) untuk mendeskripsikan aktivitas belajar siswa dalam pembelajaran geografi kelas X IPS ${ }^{1}$ SMA Negeri 1 Kabawo Pada Materi Pokok Menganalisis Hidrosfer dengan menerapkan model pembelajaran group investigation., 2) Untuk mendeskripsikan hasil belajar siswa dalam pembelajaran geografi kelas X IPS ${ }^{1}$ SMA Negeri 1 Kabawo Pada Materi Pokok Menganalisis Hidrosfer dengan menerapkan model pembelajaran group investigation., 3) Untuk mendeskripsikan aktivitas mengajar Guru dalam pembelajaran geografi siswa kelas X IPS ${ }^{1}$ SMA Negeri 1 Kabawo Pada Materi Pokok Menganalisis Hidrosfer dengan menerapkan model pembelajaran Group Investigation.Berdasarkan hasil analisis data diperoleh kesimpulan bahwa : 1) aktivitas siswa dengan penerapan model pembelajaran Group Investigation pada skor rata-rata aktivitas siswa siklus I sebesar 2,56 yang termasuk pada kategori cukup dan meningkat pada siklus II menjadi 3,0 yang berkategori baik; 2) hasil belajar geografi siswa kelas X IPS ${ }^{I}$ SMA Negeri 1 Kabawo yang diajar dengan menggunakan model pembelajaran Group Investigation pada materi pokok menganalisis hidrosfer dapat ditingkatkan dari siklus I dari 25 orang siswa ada 14 orang siswa yang tuntas dengan persentase ketuntasan 56\% dengan nilai rata-rata 71,1 sampai pada siklus II mengalami peningkatan yaitu dari 25 orang siswa ada 22 orang siswa yang tuntas dengan persentase ketuntasan $88 \%$ dengan nilai rata-rata 83,1. 3) aktivitas mengajar guru ditunjukkan dengan skor rata-rata pada siklus I adalah 2,8 yang termasuk kategori baik dan meningkat pada siklus II menjadi 3,8 yang berkategori baik.
\end{abstract}

Kata Kunci : Model Pembelajaran, Group Investigation, Hasil Belajar. 


\title{
APPLICATION OF LEARNING MODEL GROUP INVESTIGATION TO IMPROVE LEARNING RESULT OF GEOGRAPHY STUDENTS CLASS X IPS SMA NEGERI 1 KABAWO IN MATERIALS ANALYZING HYDROSPHERE
}

\author{
Risna $^{1}$, Surdin $^{2}$ \\ ${ }^{1}$ Alumni Of Geography Education FKIP UHO \\ ${ }^{2}$ Dosen Geography Education FKIP UHO
}

\begin{abstract}
The purpose of this research is to get data and description about: 1) to describe student's learning activity in class X geography lesson IPS ${ }^{I}$ SMA Negeri 1 Kabawo In Main Material Analyzing Hidrosphere by applying group investigation study model, 2) To describe student learning result in learning geography class $X$ IPS ${ }^{I}$ SMA Negeri 1 Kabawo On Main Material Analyzing Hidrosphere by applying model study group investigation., 3) To describe teaching activities Teachers in learning geography of students of class X IPS ${ }^{I}$ SMA Negeri 1 Kabawo On Main Material Analyzing Hydrosphere by applying model learning Group Investigation. Based on the result of data analysis, it can be concluded that: 1) the activity of the students with the application of Group Investigation learning model on the average score of student activity of cycle I of 2.56 which is included in the category enough and increased in cycle II to 3.0 good categorized; 2) result of study of geography of student of class X IPS I of SMA Negeri 1 Kabawo taught by using Group Investigation study on the subject matter of analyzing hydrosphere can be improved from cycle I from 25 students there are 14 complete student with percentage mastery $56 \%$ the average of 71.1 to the second cycle has increased from 25 students there are 22 students who completed with the percentage of completeness $88 \%$ with an average value of 83.1. 3) Teacher teaching activity is shown with average score in cycle I is 2.8 which belongs to good category and increase in cycle II to 3.8 which is categorized well.
\end{abstract}

Keywords: Learning Model, Group Investigation, Learning Outcomes.

\section{PENDAHULUAN}

Pendidikan adalah hak bagi setiap insan manusia, tanpa terkecuali karena negara sudah menjamin warganya untuk mendapatkan pendidikan yang layak. Pendidikan adalah usaha sadar dan terencana untuk mewujudkan suasana belajar dan proses pembelajaran agar peserta didik secara aktif mengembangkan potensi dirinya untuk memiliki kekuatan spiritual keagamaan, pengendalian diri, kepribadian, kecerdasan, akhlak mulia, serta keterampilan yang diperlukan dirinya, masyarakat, bangsa dan Negara. (UU Sisdiknas, 2003:2).

Proses pendidikan yang dilaksanakan di sekolah pada dasarnya adalah kegiatan belajar mengajar yang bertujuan agar siswa memiliki hasil yg terbaik sesuai kemampuannya. Salah satu tolak ukur yang menggambarkan tinggi rendahnya keberhasilan siswa dalam belajar adalah hasil belajar. Hasil 
belajar dapat dilihat dari tiga aspek, yaitu aspek kognitif, aspek afektif, dan aspek psikomotor. Keberhasilan proses belajar mengajar selain ditentukan oleh faktor internal siswa, juga dapat ditentukan oleh faktor eksternal siswa. Salah satu faktor eksternal yamg dapat mempengaruhi keberhasilan belajar seorang siswa adalah kemampuan guru dalam mengajar. Peran guru sangat diperlukan untuk mengaktifkan siswa dalam proses pembelajaran. Oleh karena itu, guru harus memiliki kemampuan profesional sehingga mampu meningkatkan partisipasi aktif siswa. Guru profesional adalah orang yang memiliki kemampuan dan keahlian khusus dalam bidang keguruan sehingga ia mampu melakukan tugas dan fungsinya sebagai guru dengan kemampuan maksimal (Kunandar, 2007: 46-47). Guru yang kurang profesional dalam mengajar cenderung monoton dan tidak kreatif dalam memilih model pembelajaran yang cocok untuk diterapkan dalam proses pembelajaran. Dalam artian guru dijadikan sebagai pusat dari pembelajaran dan dianggap paling tahu segalanya.

Berdasarkan observasi awal yang dilakukan peneliti, terdapat beberapa permasalahan yang ditemukan pada kelas X IPS ${ }^{I}$ SMA Negeri 1 Kabawo. Masalah pertama yang ditemukan adalah siswa cenderung lebih bergantung dari catatan yang diberikan guru saat pelajaran dikelas dan kurangnya keberanian siswa untuk mengemukakan gagasan atau pendapat dalam pembelajaran. Masalah yang kedua yaitu dalam kegiatan belajar-mengajar guru masih banyak menggunakan metode mengajar yang didominasi metode konvensional. Walaupun kadang diselingi metode diskusi, tetapi metode ini kurang efektif bagi siswa terbukti dengan sedikitnya siswa yang aktif dan masih banyak siswa yang pasif dan kurang bersemangat ketika diskusi sedang berlangsung. Hal tersebut berdampak pada hasil belajar yang kurang optimal yaitu nilai rata-rata hasil belajar geografi yang dicapai pada hasil ulangan harian pada materi pokok menganalisis hidrosfer sebesar 64,5 berada di bawah standar KKM sekolah yaitu 70 .

Yang menjadi pokok permasalahan dalam proses belajar geografi adalah rendahnya hasil belajar geografi siswa. Hal ini dikarenakan dalam kegiatan pembelajaran, guru lebih memilih pendekatan konvensional. Sistem peyampaian pelajaran oleh gurupun masih bersifat ceramah yang kemudian diakhiri dengan ujian atau kuis. Oleh karena itu, aktivitas siswa hanya seputar duduk, diam, dengar dan catat saja. Siswa lebih banyak bertindak sebagai pendengar setia dan tidak dapat menyerap materi yang disajikan oleh guru hingga tuntas. Dampaknya adalah suasana dikelas cenderung berlangsung monoton dan siswapun merasa bosan. Kondisi demikian juga berdampak pada kualitas belajar yang meliputi kualitas hasil belajar siswa yang tidak memuaskan.

Permasalahan tersebut perlu diatasi dengan menggunakan strategi pembelajaran yang baru yang dapat meningkatkan kompetensi yang dimiliki siswa. Peneliti memilih salah satu model pembelajaran cooperatif yaitu tipe group investigation untuk di terapkan dalam pembelajaran geografi bagi siswa kelas $X$ IPS $^{1}$ SMA Negeri 1 Kabawo. Tipe ini 
dipilih karena diyakini dapat membuat situasi belajar efisien dalam suatu kelompok. Selain itu, tipe pembelajaran ini menunjukkan adanya keseimbangan peran antara guru sebagai salah satu sumber belajar dan peran aktif siswa mengkontruksi pengetahuan secara individual dan sosial dengan harapan penerapan model tersebut dapat membangkitkan minat belajar siswa dengan melalui studi kelompok agar dapat memotivasi siswa untuk mengeluarkan pendapat melalui bertanya sekaligus meningkatkan hasil belajar mata pelajaran geografi Siswa kelas X IPS ${ }^{I}$ SMA Negeri 1 Kabawo.

Berdasarkan Latar belakang diatas maka peneliti tertarik untuk meneliti tentang "Penerapan Model Pembelajaran Group Investigation Untuk Meningkatkan Hasil Belajar Geografi Siswa Kelas X IPS ${ }^{\mathrm{I}}$ di SMA Negeri 1 Kabawo Pada Materi Pokok Menganalisis Hidrosfer dan Dampaknya Terhadap Kehidupan".

Menurut Endang (2013: 234) menyatakan bahwa group investigation dilakukan dengan cara melibatkan peserta didik dalam kegiatan investigasi (penelitian/penyelidikan), kegiatan peserta didik di mulai dari membuat perencanaan, menentukan topik dan cara melakukan penyelidikan untuk menyeleksi topik, layaknya sebuah penelitian. Maka sebelum peserta didik terjun untuk mengadakan investigasi maka diperlukan perencanaan: (1) apa saja yang akan di investigasi; (2) bagaimana cara melakukan investigasi; (3) alat apa yang digunakan untuk menginvestigasi; (4) bagaimana cara melaporkan hasil investigasi. Pelaksanaan metode investigasi dapat dilakukan dengan langkah-langkah sebagai berikut:

a) Guru membagi peserta didik menjadi beberapa kelompok, setiap kelompok terdiri dari 5-6 pesrta didik dengan karakteristik yang heterogen. Pembagian kelompok dapat didasarkan atas kesenangan berteman atau kesamaan minat terhadap suatu topik tertentu.

b) Kelompok memilih topik yang akan dipelajari.

c) Kelompok menyusun rencana investigasi yang berisi waktu, tempat, strategi investigasi, alat investigasi, dsb.

d) Kelompok melakukan investigasi mendalam terhadap berbagai sub topik yang telah dipilih.

e) Kelompok menulis laporan investigasi.

f) Kelompok menyiapkan dan menyajikan laporan investigasi di depan kelas.

(Kurniasih \& Sani, 2007: 25) mengatakan bahwa Model pembelajaran group investigation adalah salah satu bentuk model pembelajaran kooperatif yang memiliki titik tekan pada partisipasi dan aktivitas siswa untuk mencari sendiri materi atau segala sesuatu mengenai materi pelajaran yang akan dipelajari. Informasi tersebut bisa di dapat dari bahan-bahan yang tersedia, misalnya dari buku pelajaran, perpustakaan, atau dari internet dengan referensi yang bisa di pertanggungjawabkan. Model ini harus melibatkan siswa mulai dari perencanaan, baik dalam menentukan 
topik maupun cara untuk mempelajarinya melalui investigasi. Tipe ini menuntut para siswa untuk memiliki kemampuan yang baik dalam berkomunikasi maupun dalam keterampilan proses kelompok hal yang paling penting dari model ini adalah menumbuhkan kemampuan berfikir mandiri. Dalam teori yang ada, model pembelajaran group investigation ini ada tiga konsep utama, yaitu penelitian, pengetahuan dan dinamika kelompok. Penelitian disini adalah proses dinamika siswa memberikan respon terhadap masalah dan memecahkan masalah tersebut. Pengetahuan adalah pengalaman belajar yang di peroleh siswa baik secara langsung maupun tidak langsung. Sedangkan dinamika kelompok menunjukkan suasana yang menggambarkan sekelompok saling berinteraksi yang melibatkan berbagai ide dan pendapat serta saling bertukar pengalaman melalui proses saling berargumentasi. Model pembelajaran group investigation ini tergolong pada model yang cukup rumit, karena untuk melaksanakan model ini ada beberapa hal yang harus diperhatikan, diantaranya adalah:

1. Siswa harus memiliki kemampuan kelompok

Kemampuan kelompok yang dimaksud adalah setiap siswa harus dapat mengerjakan materi dalam kelompoknya dan mereka harus mendapat kesempatan memberikan kontribusi masing-masingnya. Dalam penyelidikan, siswa dapat mencari informasi dari berbagai informasi dari dalam maupun di luar kelas, kemudian siswa mengumpulkan informasi yang di berikan dari setiap anggota untuk mengerjakan lembar kerja.

2. Siswa harus memiliki rencana kooperatif

Siswa bersama-sama menyelidiki masalah mereka, sumber mana yang mereka butuhkan, siapa yang melakukan apa, dan bagaimana mereka akan mempresentasikan proyek mereka di dalam kelas.

3. Peran guru

Di samping jadi fasilitator, guru juga harus menyediakan sumber sumber. Dan guru juga harus berkeliling diantara kelompok-kelompok dan memperhatikan siswa mengatur pekerjaan dan membantu siswa mengatur pekerjaannya dan membantu jika siswa menemukan kesulitan dalam interaksi kelompok.

Keberhasilan pengajaran dapat di lihat dari segi hasil. Asumsi dasar adalah proses pengajaran yang optimal memungkinkan hasil belajar yang optimal pula. Ada korelasi antara proses pengajaran dengan hasil yang dicapai. Makin besar usaha untuk menciptakan kondisi proses pengajaran, semakin tinggi pula hasil atau produk dari pengajaran itu. Hasil belajar pada dasarnya terjadinya proses perubahan tingkah laku dari tidak tahu menjadi tahu,dari sikap yang kurang baik menjadi lebih 
baik,dari tidak terampil menjadi terampil pada siswa (Supardi,2015:2).

Menurut Wina (2008: 13) mengatakan bahwa hasil belajar berkaitan dengan pencapaian dalam memperoleh kemampuan sesuai dengan tujuan khusus yang direncanakan. Dengan demikian, tugas utama guru dalam kegiatan ini adalah merancang instrument yang dapat mengumpulkan data tentang keberhasilan siswa mencapai tujuan pembelajaran. Berdasarkan data tersebut guru dapat mengembangkan dan memperbaiki program pembelajaran.Sedangkan Jamil (2013: 37) mengatakan bahwa hasil belajar sangat erat kaitannya dengan belajar atau proses belajar. Hasil belajar pada sasarannya dikelompokkan dalam dua kelompok, yaitu pengetahuan dan keterampilan. Pengetahuan dibedakan menjadi: empat macam, yaitu pengetahun tentang fakta-fakta, pengetahuan tentang prosedur, pengetahuan konsep, dan keterampilan berinteraksi.

\section{METODE PENELITIAN}

Penelitian ini dilaksanakan di SMA Negeri 1 Kabawo. Waktu pelaksanaan penelitian pada bulan
Maret-April 2018.Pendekatan yang di gunakan dalam penelitian ini adalah Penelitian Tindakan Kelas (PTK), atau istilah dalam bahasa inggrisnya adalah Classroom Action Research (CAR). Adapun Subjek dalam penelitian ini adalah siswa kelas $\mathrm{X}$ IPS $^{1}$ SMA Negeri 1 Kabawo yang terdaftar pada tahun 2017/2018 dengan jumlah siswa sebanyak 25 orang terdiri dari 13 siswa laki-laki dan 12 siswa perempuan. Kelas ini dipilih sebagai subyek penelitian karena nilai rata-rata hasil ulangan geografi yang dicapai pada hasil ulangan harian sebesar 64,5 berada di bawah standar KKM sekolah yaitu 70 .

\section{HASIL PENELITIAN}

Data mengenai aktifitas siswa kelas X IPS ${ }^{1}$ SMA Negeri 1 Kabawo selama pembelajaran dengan model pembelajaran Group Investigation diambil dengan menggunakan lembar observasi dengan cara memberikan skor pada setiap aspek aktivitas yang dilakukan oleh siswa sesuai dengan kriteria yang ditentukan. Data mengenai distribusi rata-rata persatuan aktivitas siswa pada setiap siklus dapat dilihat pada tabel 3.1 berikut:

Tabel 3.1 Rata-Rata Aktivitas Belajar Siswa pada setiap Siklus

\begin{tabular}{llcc}
\hline \multirow{2}{*}{ No } & \multirow{2}{*}{ Aktivitas Siswa } & \multicolumn{2}{c}{ Rata-Rata Hasil Per } \\
\cline { 3 - 4 } & & S & II \\
\hline 1 & Mengidentifikasi topic & 2,9 & 3,1 \\
\hline 2 & Merencanakan tugas & 2,6 & 3,4 \\
\hline 3 & Membuat penyelidikan & 2,1 & 2,9 \\
\hline 4 & Mempersiapkan tugas akhir & 2,65 & 2,8 \\
\hline 5 & Mempresentasikan tugas akhir & 2,75 & 3 \\
\hline 6 & Mampu menyelesaikan tugas evaluasi & 2,4 & 3,1 \\
\hline & Rata-rata Aktivitas Siswa & 2,56 & 3,0 \\
\hline
\end{tabular}


Sumber: Data diolah (2018)

Dari tabel 3.1 tersebut terlihat bahwa pada siklus 1 aktivitas siswa terendah terdapat pada aspek membuat penyelidikan, mampu merencanakan tugas dan menyelesaikan tugas akhir, sedangkan aktivitas siswa tertinggi terdapat pada aspek mengidentifikasi topik, mempresentasikan tugas akhir, dan mempersiapkan tugas akhir. Pada siklus II terlihat bahwa setiap aspek yang diamati mengalami peningkatan. Aktivitas siswa yang terendah di siklus I meningkat menjadi 2,9 sedangkan aktivitas siswa tertinggi di siklus I meningkat menjadi 3,1 .

\section{Data Hasil Belajar Siswa}

Data hasil belajar geografi di peroleh dengan menggunakan tes hasil belajar. Berdasarkan analisis deskriptif terhadap hasil belajar geografi siswa pada materi pokok hidrosfer ditunjukkan dalam bentuk tes siklus yang terdiri dari tes siklus I dan tes siklus II diperoleh data sebagai berikut:

Tabel 3.2 Hasil Analisis Deskriptif

\begin{tabular}{clll}
\hline No & \multicolumn{1}{c}{ Nilai } & Siklus I & Siklus II \\
\hline 1 & Minimum & 41,6 & 45,8 \\
\hline 2 & Maksimum & 91,6 & 95,8 \\
\hline 3 & Rata-rata & 71,1 & 83,1 \\
\hline 4 & Standar deviasi & 14,6 & 11,7 \\
\hline & Dari tabel 3.2 tersebut & menunjukkan & adanya \\
terlihat bahwa hasil belajar & peningkatan hasil belajar \\
geografi siswa kelas X IPS & geografi siswa dari siklus I ke \\
SMA Negeri 1 Kabawo pada & siklus II terlihat jelas jelas dari \\
materi pokok hidrosfer setelah & nilai minimum, nilai maksimum, \\
diajar dengan menerapkan & nilai rata-rata dan standar \\
model pembelajaran group & deviasinya. Ketuntasan belajar \\
investigationmenunjukkan & siswa secara klasikal tiap siklus \\
adanya peningkatan dari siklus I & dapat dilihat pada tabel 3.4 \\
ke siklus II. Hal tersebut juga & sebagai berikut:
\end{tabular}

dapat dilihat pada gambar 3.3

Tabel 3.3 Deskripsi Ketuntasan Belajar Siswa

\begin{tabular}{lccccc}
\hline & \multirow{2}{*}{ Nenis } & \multicolumn{4}{c}{ Ketuntasan } \\
\cline { 3 - 6 } & Evaluasi & \multicolumn{2}{c}{ Tuntas } & \multicolumn{2}{c}{ Belum Tuntas } \\
\cline { 3 - 6 } & & $\begin{array}{c}\text { Frekuensi } \\
(\text { Orang) }\end{array}$ & $\begin{array}{c}\text { Persentase } \\
(\boldsymbol{\%})\end{array}$ & $\begin{array}{c}\text { Frekuensi } \\
(\text { Orang) }\end{array}$ & $\begin{array}{c}\text { Persentase } \\
(\boldsymbol{\%})\end{array}$ \\
\hline 1. & Siklus I & 14 & 56 & 11 & 44 \\
\hline 2. & Siklus II & 22 & 88 & 3 & 12 \\
\hline
\end{tabular}


Untuk lebih jelasnya gambaran jumlah siswa yang sudah tuntas dengan belum tuntas belajar pada tiap siklus dapat dilihat pada gambar 3.1 berikut:

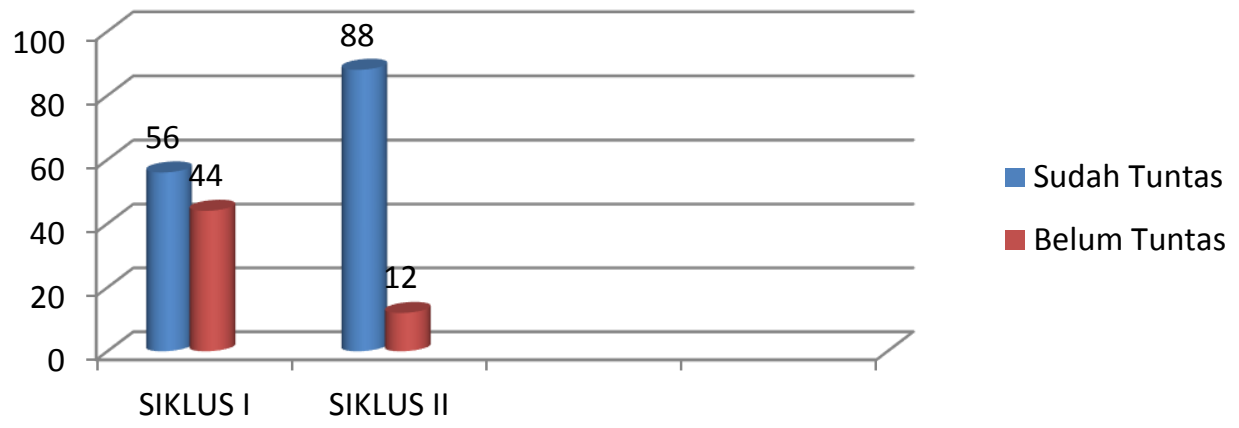

Gambar 3.1 Grafik Persentase Jumlah Siswa Sudah Tuntas Dan Belum TuntasBelajar

Dari gambar 3.1 tersebut terlihat bahwa terjadi peningkatan persentase ketuntasan belajar dari siklus I ke siklus II, pada siklus I persentase ketuntasan sebesar $56 \%$ atau 14 orang siswa telah mencapai KKM (Kriteria Ketuntasan Minimum) dan ketuntasan secara klasikal belum terpenuhi yaitu $80 \%$ dari 11 siswa mencapai nilai minimal 70 dan pada siklus II persentase ketuntasan sebesar $88 \%$ atau 22 orang siswa telah mencapai KKM, dengan demikian ketuntasan secara klasikal dari penelitian tindakan kelas ini telah terpenuhi yang berarti pula model pembelajaran group investiagation dapat memecahkan masalah belajar siswa kelas X IPS ${ }^{1}$.

KKM ( Kriteria Ketuntasan Minimum ) dari ketuntasan secara klasikal belum terpenuhi yaitu $80 \%$ dari 11 orang siswa mencapai nilai minimal 70 dan pada siklus II persentase ketuntasan sebesar $88 \%$ atau 22 orang siswa telah mencapai $\mathrm{KKM}$, dengan demikian ketuntasan secara klasikal dari penelitian tindakan kelas ini telah terpenuhi yang berarti pada model pembelajaran group investigation dapat memecahkan masalah belajar siswa kelas X IPS ${ }^{1}$.

\section{Aktivitas Mengajar Guru \\ Data mengenai aktivitas mengajar guru dalam mengelola pembelajaran dengan menerapkan model pembelajaran Group Investigation pada materi menganalisis hidrosfer dengan menggunakan lembar pengamatan aktivitas mengajar guru dalam kegiatan belajar mengajar dengan memberikan skor pada aspek yang diamati pada siklus I dan siklus II setiap masing-masing pertemuan.}

\section{SIKLUS I}

Data aktivitas mengajar guru yang diperoleh dengan menggunakan lembar pengamatan aktivitas mengajar guru siklus I pada pertemuan I dan pertemuan II dapat dilihat pada tabel 3.4 
Tabel 3.4 data aktivitas mengajar guru siklus I

\begin{tabular}{|c|c|c|c|c|}
\hline \multirow{3}{*}{ No } & \multirow{3}{*}{ Aktivitas Yang Diamati } & \multicolumn{3}{|c|}{ Siklus I } \\
\hline & & \multicolumn{2}{|c|}{$\begin{array}{c}\text { Pertemuan } \\
\text { ke- }\end{array}$} & \multirow{2}{*}{$\begin{array}{c}\operatorname{Re} \\
\text { rat } \\
\mathbf{a}\end{array}$} \\
\hline & & 1 & 2 & \\
\hline & A. Kegiatan Awal & & & \\
\hline 1 & Guru memberi salam kepada peserta didik & 3 & 3 & 3 \\
\hline 2 & $\begin{array}{l}\text { Guru memperhatikan kehadiran peserta didik dan } \\
\text { menanyakan siswa yang tidak masuk }\end{array}$ & 2 & 3 & 2,5 \\
\hline 3 & Guru melakukan persepsi & 2 & 3 & 2,5 \\
\hline \multirow[t]{2}{*}{4} & Guru memberikan motivasi & 2 & 3 & 2,5 \\
\hline & B. Kegiatan Inti & & & \\
\hline 5 & $\begin{array}{l}\text { Guru menentukan sub topik dalam suatu materi } \\
\text { kemudian membagi kelompok menjadi } 5 \text { kelompok } \\
\text { yang terdiri 5-6 orang yang heterogen. }\end{array}$ & 2 & 3 & 2,5 \\
\hline 6 & $\begin{array}{l}\text { Guru mengarahkan kepada tiap-tiap kelompok untuk } \\
\text { melakukan kegiatan sesuai dengan petunjuk dalam } \\
\text { LKS }\end{array}$ & 3 & 3 & 3 \\
\hline 7 & $\begin{array}{l}\text { Guru membimbing kelompok-kelompok dalam } \\
\text { merumuskan pemecahan masalah dan menentukan } \\
\text { sumber-sumber yang tepat }\end{array}$ & 4 & 4 & 4 \\
\hline 8 & $\begin{array}{l}\text { Guru memantau siswa dalam menerapkan rencana } \\
\text { yang telah mereka kembangkan dan guru menawarkan } \\
\text { bantuan bila diperlukan }\end{array}$ & 3 & 3 & 3 \\
\hline 9 & $\begin{array}{l}\text { Guru mengarahkan dan membimbing siswa dalam } \\
\text { menganalisis dan mengevaluasi proses pemecahan } \\
\text { masalah. }\end{array}$ & 3 & 3 & 3 \\
\hline 10 & $\begin{array}{l}\text { Guru membimbing kelompok dalam menyajikan hasil } \\
\text { penyelidikan kepada seluruh kelas dan masing-masing } \\
\text { kelompok mempersentasikan hasil/temuan } \\
\text { investigasinya didepan kelas }\end{array}$ & 3 & 3 & 2,5 \\
\hline \multirow[t]{2}{*}{11} & $\begin{array}{l}\text { Guru dan siswa berkolaborasi dalam mengevaluasi } \\
\text { pembelajaran siswa. Evaluasi yang dilakukan dapat } \\
\text { berupa penilaian individu dan kelompok. }\end{array}$ & 2 & 2 & 2 \\
\hline & C. Kegiatan Penutup & & & \\
\hline 12 & Memberikan apresiasi terhadap semua siswa yang & 2 & 3 & 2,5 \\
\hline
\end{tabular}


terlibat aktif dan kondusif selama kegiatan

pembelajaran berlangsung

\begin{tabular}{|c|c|c|c|c|}
\hline 13 & $\begin{array}{l}\text { Peserta didik bersama guru membuat kesimpulan hasil } \\
\text { pembelajaran }\end{array}$ & 3 & 4 & 3,5 \\
\hline 14 & Guru menutup pembelajaran & 3 & 3 & 3 \\
\hline
\end{tabular}

\section{Rerata}

$2,6 \quad 3,0 \quad 2,8$

Berdasarkan tabel 3.4 diperoleh gambaran aktivitas mengajar guru pada sikls I dari pertemuan I sampai pertemuan II. Pada siklus I guru mendapatkan skor terendah dengan nilai rata-rata 2 adalah aktivitas nomor 11) Guru dan siswa berkolaborasi dalam mengevaluasi pembelajaran siswa. Evaluasi yang dilakukan dapat berupa penilaian individu dan kelompok. Sedangkan skor tertinggi aktivitas mengajar guru dengan skor rata-rata 4 terdapat pada aktivitas nomor 7) Guru membimbing kelompok-kelompok dalam merumuskan pemecahan masalah dan menentukan sumber-sumber yang tepat.

Berdasarkan analisis data yang terlihat pada tabel 3.4 menunjukkan bahwa aktivitas guru belum mencapai keberhasilan karena belum menjawab hipotesis tindakan, dimana skor rata-rata aktivitas mengajar guru pada pertemuan I siklus I sebesar 2,6 berada dalam kategori cukup dan skor rata-rata aktivitas mengajar guru pada pertemuan II siklus I sebesar 3,0 yang berada dalam kategori baik, tetapi pada siklus I ini setelah dirata-ratakan antara pertemuan I dan pertemuan II aktivitas mengajar guru masih berada dalam kategori cukup dengan skor sebesar 2,8.

\section{SIKLUS II}

Data aktivitas mengajar guru yang diperoleh dengan menggunakan lembar pengamatan aktivitas mengajar guru siklus II pada pertemuan I dan pertemuan II dapat dilihat pada tabel 3.6 berikut ini :

Tabel 3.5 data aktivitas mengajar guru siklus II

\begin{tabular}{|c|c|c|c|c|}
\hline \multirow{3}{*}{ No } & \multirow{3}{*}{ Aktivitas Yang Diamati } & \multicolumn{3}{|c|}{ Siklus I } \\
\hline & & \multicolumn{2}{|c|}{$\begin{array}{c}\text { Pertemuan } \\
\text { Ke- }\end{array}$} & \multirow{2}{*}{$\begin{array}{c}\mathbf{R e} \\
\text { rat } \\
\mathbf{a}\end{array}$} \\
\hline & & 1 & 2 & \\
\hline & \multicolumn{4}{|l|}{ A. Kegiatan Awal } \\
\hline 1 & Guru memberi salam kepada peserta didik & 4 & 4 & 4 \\
\hline 2 & $\begin{array}{l}\text { Guru memperhatikan kehadiran peserta didik dan } \\
\text { menanyakan siswa yang tidak masuk }\end{array}$ & 4 & 4 & 4 \\
\hline 3 & Guru melakukan persepsi & 4 & 4 & 4 \\
\hline
\end{tabular}




\begin{tabular}{|c|c|c|c|c|}
\hline 4 & Guru memberikan motivasi & 3 & 4 & 3,5 \\
\hline & \multicolumn{4}{|l|}{ B. Kegiatan Inti } \\
\hline 5 & $\begin{array}{l}\text { Guru menentukan sub topik dalam suatu materi } \\
\text { kemudian membagi kelompok menjadi } 5 \text { kelompok } \\
\text { yang terdiri 5-6 orang yang heterogen. }\end{array}$ & 4 & 4 & 4 \\
\hline 6 & $\begin{array}{l}\text { Guru mengarahkan kepada tiap-tiap kelompok untuk } \\
\text { melakukan kegiatan sesuai dengan petunjuk dalam } \\
\text { LKS }\end{array}$ & 4 & 4 & 4 \\
\hline 7 & $\begin{array}{l}\text { Guru membimbing kelompok-kelompok dalam } \\
\text { merumuskan pemecahan masalah dan menentukan } \\
\text { sumber-sumber yang tepat }\end{array}$ & 4 & 4 & 4 \\
\hline 8 & $\begin{array}{l}\text { Guru memantau siswa dalam menerapkan rencana } \\
\text { yang telah mereka kembangkan dan guru menawarkan } \\
\text { bantuan bila diperlukan }\end{array}$ & 3 & 3 & 3 \\
\hline 9 & $\begin{array}{l}\text { Guru mengarahkan dan membimbing siswa dalam } \\
\text { menganalisis dan mengevaluasi proses pemecahan } \\
\text { masalah. }\end{array}$ & 3 & 4 & 3,5 \\
\hline 10 & $\begin{array}{l}\text { Guru membimbing kelompok dalam menyajikan hasil } \\
\text { penyelidikan kepada seluruh kelas dan masing-masing } \\
\text { kelompok mempersentasikan hasil/temuan } \\
\text { investigasinya didepan kelas }\end{array}$ & 4 & 4 & 4 \\
\hline \multirow[t]{2}{*}{11} & $\begin{array}{l}\text { Guru dan siswa berkolaborasi dalam mengevaluasi } \\
\text { pembelajaran siswa. Evaluasi yang dilakukan dapat } \\
\text { berupa penilaian individu dan kelompok. }\end{array}$ & 4 & 4 & 4 \\
\hline & \multicolumn{4}{|l|}{ C. Kegiatan Penutup } \\
\hline 12 & $\begin{array}{l}\text { Memberikan apresiasi terhadap semua siswa yang } \\
\text { terlibat aktif dan kondusif selama kegiatan } \\
\text { pembelajaran berlangsung }\end{array}$ & 4 & 4 & 4 \\
\hline 13 & $\begin{array}{l}\text { Peserta didik bersama guru membuat kesimpulan hasil } \\
\text { pembelajaran }\end{array}$ & 3 & 4 & 3,5 \\
\hline \multirow[t]{2}{*}{14} & \multirow[t]{2}{*}{ Guru menutup pembelajaran } & 4 & 4 & 4 \\
\hline & & 3,7 & 3,9 & 3,8 \\
\hline & $\begin{array}{l}\text { Berdasarkan tabel } 3.5 \\
\text { njukkan bahwa aktivitas mengajar } \\
\text { pertemuan I di siklus II berada } \\
\text { n kategori baik dengan skor sebesar }\end{array}$ & $\begin{array}{l}\text { meng } \\
\text { II be } \\
\text { n me } \\
\text { ri pe }\end{array}$ & $\begin{array}{l}\text { gur } \\
\text { pula } \\
\text { ki nil } \\
\text { nuan }\end{array}$ & $\begin{array}{l}\text { pada } \\
\text { lam } \\
\text { rata- } \\
\text { jaitu }\end{array}$ \\
\hline
\end{tabular}


3,9. Rata-rata aktivitas guru dari pertemuan I sampai pertemuan II setelah dirata-ratakan berada dalam kategori baik dengan skor sebesar 3,8.

Berdasarkan analisis data yang terlihat pada tabel 3.5 menunjukkan bahwa aktivitas guru telah memenuhi kriteria, dimana dikatakan berhasil apabila telah mencapai skor rata-rata minimal 3,0. Skor rata-rata aktivitas guru di siklus II sebesar 3,8 menunjukkan bahwa penerapan model pembelajaran group investigation pada materi pokok menganalisis hidrosfer dapat meningkatkan aktivitas guru.skor rata-rata aktivitas belajar siswa sebesar 3,0 .

\section{PEMBAHASAN}

1. Aktivitas Siswa selama KBM Berlangsung.

Berdasarkan permasalahan pertama tentang bagaimana gambaran aktivitas belajar siswa dalam proses belajar mengajar pada materi pokok hidrosfer yang diajar dengan menerapkan model pembelajaran group investigation, dapat dijelaskan berdasarkan hasil pengamatan pada setiap siklus baik siklus I maupun siklus II yang menunjukkan peningkatan ke arah yang lebih baik, dimana rata-rata aktivitas belajar siswa dapat dilihat pada tabel 3.1 peningkatan aktivitas belajar siswa tersebut menunjukkan adanya minat dan antusias siswa dalam mengikuti pembelajaran pada materi hidrosfer dengan penerapan model pembelajaran group investigation.

\section{SIKLUS I}

Berdasarkan hasil analisis deskriptif terhadap persatuan aktivitas belajar siswa pada siklus I, seperti yang terlihat pada tabel 3.1 menunjukkan bahwa rata-rata aktivitas pada siklus I adalah sebesar 2,56. Pada siklus I beberapa aktivitas siswa tergolong kurang dimana siswa masih belum terbiasa dengan model pembelajaran group investigation kelompok diantaranya: membuat penyelidikan tentang siklus hidrologi dan menyelesaikan tugas evaluasi. Hal ini karena siswa tidak terbiasa melakukan penyelidikan terhadap materi yang diberikan, melainkan menunggu bahan yang diberikan oleh guru kelas. Apalagi kerjasama melakukan kegiatan investigation karena dalam proses pembelajaran guru lebih mendominasi.

Hal ini terlihat pada aktivitas guru pada siklus ini kurang membimbing siswa untuk membuat penyelidikan pada materi siklus hidrologi dan menyelesaikan tugas evaluasi. Untuk mengatasi persoalan tersebut, guru mata pelajaran geografi bersama peneliti melakukan analisis dan refleksi terhadap faktor-faktor yang menyebabkan kurangnya intensitas beberapa aktivitas siswa dalam model pembelajaran ini dan disepakati adanya beberapa kelemahan siswa dalam menerapkan model pembelajaran group investigation dikelas khususnya materi siklus hidrologi, yakni: 
1) Siswa kurang mampu membuat penyelidikan tentang siklus hidrologi.

2) Siswa kurang mampu menyelesaikan tugas evaluasi tentang materi yang dipelajari.

Berdasarkan hasil analisis dan refleksi tersebut, guru memperbaiki cara mengajarkan materi siklus hidrologi yang sesuai dengan model pembelajaran group investigation dan memperbaharui aktivitas yang masih kurang, baik secara kualitas maupun kuantitasnya pada siklus II, yaitu dengan membimbing siwa mencari sendiri materi/topik dari berbagai sumber serta lebih memperhatikan presentasi yang dilakukan setiap kelompok agar siswa dapat menyelesaikan tugas evaluasi. Sehimgga diharapkan pada pertemuan selanjutnya diperoleh peningkatan disemua satuan aktivitas pembelajaran.

\section{SIKLUS II}

Fenomena tentang materi pelajaran serta melakukan evaluasi untuk mengukur pencapaian kompetensi siswa tentang materi pelajaran yang baru dipelajari. Padahal beberapa aspek ini juga sangat penting dalam model pembelajaran group investigation. Dimana pada saat aktivitas ini dilakukan maka akan terlihat siswa dilatih untuk melakukan investigasi tentang siklus hidrologi, kemudian menyelesaikan tugas evaluasi tentang materi yang dipelajari. Akibatnya seperti yang nampak pada hasil analisis aktivitas siswa pada siklus I dimana siswa kurang menyelesaikan berbagai topik yang diselidiki.

Dari hasil analisis deskriptif terhadap aktivitas siswa pada siklus II menunjukkan adanya peningkatan aktivitas siswa yang sangat signifikan dari siklus I. Hal ini terlihat pada tabel 3.1 menunjukkan adanya peningkatan nilai aktivitas siswa dalam melakukan investigasi tentang siklus hidrologi dengan rata-rata 2,1 pada siklus 1 menjadi 2,9 pada siklus II. Selain itu terdapat peningkatan rata-rata siswa menyelesaikan tugas evaluasi yaitu rata-rata 2,4 pada siklus I menjadi 3,1. Dengan demikian dengan skor rata-rata aktivitas siswa pada siklus I sebesar 2,56 meningkat pada siklus II menjadi 3,0.

2. Hasil Belajar Siswa

Berdasarkan permasalahan kedua, tentang bagaimana gambaran hasil belajar geografi siswa kelas X IPS ${ }^{I}$ SMA Negeri 1 Kabawo pada materi siklus hidrologi setelah diajar melalui penerapan model pembelajaran group investigation, dapat dijelaskan bahwa berdasarkan hasil analisis deskriptif yang dilakukan terhadap hasil belajar siswa pada setiap siklus cenderung mengalami peningkatan kearah yang lebih baik, hal ini dapat dilihat pada tabel 3.2.

\section{SIKLUS I}

Berdasarkan hasil analisis deskriptif terhadap hasil belajar siswa pada siklus I dengan sub materi pokok siklus hidrologi dengan skor minimum sebesar 
41,6; nilai maksimum 91,6; ratarata hasil belajar siswa sebesar 71,1 dengan standar deviasi sebesar 14,6. Pada kondisi ini ternyata terdapat 11 orang siswa atau $44 \%$ siswa yang nilainya masih dibawah KKM yang ditentukan oleh sekolah yaitu $\geq 70$ dan hanya 14 orang siswa atau $56 \%$ siswa yang memperoleh nilai $\geq 70$.

Dari data tersebut, terlihat bahwa dalam pembelajaran ini tampak bahwa siswa kurang membaca buku teks/LKS atau sumber dalam kegiatan investigasi dan siswa kurang berdiskusi bersama teman kelompoknya, serta siswa siswa kurang memperhatikan presentasi dari kelompok lain. Dari beberapa hal tersebut diduga berpengaruh pada hasil belajar geografi siswa, khususnya bagi siswa yang belum mencapai KKM (Kriteria Ketuntasan Minimum).

Setelah melakukan analisis dan refleksi pada siklus I, guru mata pelajaran dan peneliti mencoba mengadakan beberapa perbaikan dalam proses belajar mengajar yaitu dengan membimbing siswa dalam menginvestigasi topik yang diberikan dan lebih aktif dalam diskusi kelompoknya, serta memperhatikan presentasi yang dilakukan oleh kelompok lain agar pada siklus selanjutnya siswa yang kurang memenuhi ketuntasan belajar dapat meningkat lagi.

\section{SIKLUS II}

Berdasarkan hasil analisis deskriptif terhadap hasil belajar siswa pada siklus II terlihat bahwa hasil belajar pada sub materi peraiaran laut dengan skor minimum sebesar 45,8; skor maksimum 95,8; rata-rata hasil belajar siswa sebesar 83,1 dengan standar deviasi sebesar 11,7. Dari data tersebut menunjukkan peningkatan kearah yang lebih baik walaupun masih ada 3 orang siswa yang belum mencapai ketuntasan belajar atau nilainya yaitu $\leq 70$. Hal ini dimungkinkan disebabkan karena kurangnya kemampuan siswa mengingat materi pelajaran yang telah dipelajari.

Dari hasil analisis deskriptif terhadap peningkatan hasil belajar siswa menunjukkan adanya peningkatan hasil belajar yang signifikan dari siklus I ke siklus II. Peningkatan hasil belajar siswa pada siklus II yaitu pada sub materi pokok perairan laut menunjukkan adanya peningkatan penguasaan siswa terhadap materi pokok siklus hidrologi. Hal ini disebabkan guru telah mampu mengelola pembelajaran dengan menerapkan model pembelajaran group investigation dengan baik terlihat dari tingginya hasil belajar minimal secara individu dan klasikal seperti dipersyaratkan kurikulum.

Berdasarkan hipotesis tindakan penelitian ini dianggap berhasil ditunjukkan dengan peningkatan nilai rata-rata hasil belajar siswa pada siklus I sebesar 71,1 dengan persentase yang sudah tuntas sebesar $56 \%$ dan pada siklus II rata-rata hasil belajar meningkat menjadi 83,1 dengan persentase siswa yang sudah tuntas sebesar 88 $\%$. 
Dengan demikian, jawaban atas permasalahan penelitian telah terungkap yakni pembelajaran dengan model group investigation meningkatkan aktivitas dan hasil belajar siswa sekaligus dapat mencapai kriteria ketuntasan minimum dalam pembelajaran geografi khususnya pada materi po kok Menganalisis Hidrosfer.

3. Aktivitas Mengajar Guru

Pelaksanaan penelitian tindakan kelas (PTK) dengan menerapkan model pembelajaran group investigation dalam pembelajaran geografi untuk materi pokok menganalisis hidrosfer dilakukan sebanyak 4 (empat) kali pertemuan dengan 2 (dua) siklus. Siklus I terdiri dari 2 (dua) kali pertemuan yaitu pertemuan pertama membahas materi siklus hidrologi dan jenis-jenis perairan darat dan pertemuan kedua mengklasifikasi ciri dan pola aliran sungai dan menganalisis penyebab kerusakan dan upaya pelestarian DAS.

Pada siklus II juga terdiri dari 2 (dua) kali pertemuan yaitu menjelaskan perbedaan pesisir dan pantai dan mengklasifikasikan jenis-jenis laut serta mengidentifikasi morfologi laut, pertemuan keempat membahas materi tentang menjelaskan gerakan air laut dan mengidentifikasi kualitas air laut indonesia serta membedakan batas perairan laut indonesia. Pelaksanaan pembelajaran tiap pertemuan terdapat kegiatan yang dilakukan sesuai dengan langkah-langkah model pembelajaran group investigation yang termuat dalam RPP.

Berdasarkan permasalahan
kedua yaitu bagaimanakah gambaran aktivitas mengajar guru dalam mata pelajaran geografi melalui penerapan model pembelajaran group investigation pada siswa SMA Negeri 1 Kabawo kelas X IPS ${ }^{\mathrm{I}}$ dapat dijelaskan bahwa berdasarkan hasil pengamatan aktivitas mengajar guru baik pada siklus I maupun pada siklus II dari cukup mengarah kearah yang lebih baik seperti yang terlihat pada tabel 3.4 dan 3.5 dimana rata-rata aktivitas mengajar guru dari kategori cukup pada siklus I menuju kearah yang lebih baik pada siklus II.

Berdasarkan hasil observasi aktivitas guru pada siklus I diperoleh kekurangan-kekurangan aktivitas mengajar guru dalam pembelajaran yang dibawakan oleh guru yang tidak maksimal.

Pada siklus I berdasarkan analisis dan evaluasi aktivitas mengajar guru menunjukkan skor rata-rata aktivitas mengajar guru pada siklus I adalah 2,8 yang berada dalam kategori cukup.

Berdasarkan analisis deskriptif pada siklus II semua aspek aktivitas guru mengalami peningkatan. Skor aktivitas yang mendapatkan nilai terendah disiklus I dengan skor rata-rata 2 meningkat disiklus II. Dimana aktivitas pada nomor 11 disiklus II memperoleh skor 4. Berdasarkan tabel 3.4 dan 3.5 dianalisis dari data pedoman pengamatan aktivitas mengajar guru melalui penerapan model 
pembelajaran group investigation pada materi pokok menganalisis hidrosfer rata-rata aktivitas mengajar guru pada siklus I berkategori cukup mengarah ke kategori baik pada siklus II.

Pada siklus II aktivitas mengajar guru menunjukkan adanya peningkatan yang signifikan dimana rata-rata aktivitas mengajar guru memperoleh nilai 3,8 yang berada pada kategori baik. Hasil analisis dari pengamatan pada siklus II menunjukkan adanya peningkatan aktivitas mengajar guru dari 2,8 pada siklus I menjadi 3,8 pada siklus II dengan menerapkan model pembelajarangroup investigation.

4. Presentase Peningkatan Hasil Belajar

Pada siklus I persentase hasil belajar siswa sangat rendah dari 25 siswa yang mengikuti tes tingkat ketuntasan hasil belajar siswa hanya mencapai $56 \%$ dari 25 siswa yang ikut tes hanya 14 orang yang dinyatakan lulus sedangkan yang tidak lulus mencapai $44 \%$ atau dari 25 siswa yang ikut tes sebanyak 16 orang siswa tidak lulus. Hasil ini tentu saja membuat peneliti harus memperbaiki disiklus berikutnya. Setelah peneliti dan guru menjadi observer berdiskusi ditetapkan untuk melanjutkan ketahap selanjutnya. Pada siklus II persentase hasil belajar siswa mengalami peningkatan dari 25 siswa yang ikut tes ketuntasan hasil belajar siswa mencapai $88 \%$ atau ada 22 orang siswa yang lulus sedangkan yang tidak lulus mencapai $12 \%$ atau terdapat 3 orang siswa. Hal ini membuktikan ada peningkatan hasil belajar dari siklus I ke siklus II yang sangat signifikan. Peningkatan sebesar $38 \%$ yang diperoleh dari selisih antara persentase ketuntasan siklus II dan siklus I. Dimana pada siklus I persentase ketuntasan hasil belajar siswa sebesar $56 \%$ dan pada siklus 2 persentase ketuntasan hasil belajar siswa sebesar $88 \%$.

Dengan demikian jawaban atas permasalahan penelitian ini telah terjawab yaitu pembelajaran dengan menerapkan model pembelajaran group investigation berhasil meningkatkan hasil belajar siswa kelas X IPS ${ }^{I}$ SMA Negeri 1 Kabawo pada materi pokok menganalisis hidrosfer. Penelitian ini dikatakan berhasil karena hipotesis tindakan telah terjawab.

\section{PENUTUP}

Berdasarkan rumusan masalah dan hasil-hasil analisis data penelitian dapat ditarik kesimpulan sebagai berikut:

1. Gambaran aktivitas siswa dengan penerapan model pembelajaran group investigation pada setiap siklus cenderung membaik dan meningkat. Hal ini di tunjukkan dengan skor rata-rata aktivitas siswa pada siklus I sebesar 2,56 meningkat pada siklus II menjadi 3 .

2. Gambaran hasil belajar siswa kelas $X$ IPS $^{1}$ SMA Negeri 1 Kabawo yang diajar dengan menggunakan model pembelajaran group investigation yang diperoleh sebaran nilai: pada siklus I diperoleh nilai dari 41,6 sampai 
dengan 91,6 pada siklus II di peroleh nilai dari 45,8 sampai dengan 95,8 .

3. Aktivitas mengajar guru dengan menerapkan model pembelajaran group investigation pada setiap siklus cenderung meningkat. Hal ini ditunjukkan dengan skor ratarata pada setiap siklus, dimana pada siklus I skor rata-rata aktivitas guru adalah 2,8 yang termasuk kategori baik dan meningkat pada siklus II menjadi 3,8 yang berkategori baik.

4. Hasil belajar geografi siswa kelas $X$ IPS $^{1}$ SMA Negeri 1 Kabawo pada materi pokok hidrosfer dapat ditingkatkan dengan menerapkan model pembelajaran group investigation. Hal ini ditunjukkan oleh nilai yang diperoleh setiap individu cenderung mengalami peningkatan dari siklus I sampai siklus II yang ditunjukkan oleh nilai rata-rata hasil belajar siswa pada siklus I sebesar 71,1 dengan persentase yang sudah tuntas sebesar $56 \%$ dan pada siklus II rata-rata hasil belajar siswa meningkat menjadi 83,1 dengan persentase yang sudah tuntas sebesar $88 \%$.

Berdasarkan hasil penelitian upaya meningkatkan hasil belajar geografi pada materi pokok menganalisis hidrosfer dan dampaknya terhadap kehidupan di muka bumi melalui model pembelajaran group investigation siswa kelas X IPS ${ }^{1}$ SMA Negeri 1 Kabawo, maka saran yang dapat diberikan sebagai sumbangan pemikiran untuk meningkatkan mutu pendidikan pada umumnya dan meningkatkan hasil belajar siswa SMA
Negeri 1 Kabawo pada khususnya sebagai berikut:

1. Bagi siswa, hendaknya dapat berperan aktif dengan menyampaikan ide atau pemikirannya pada proses pembelajaran sehingga kegiatan belajar mengajar dapat berjalan efektif sesuai dengan yang diharapkan.

2. Bagi guru

a. Guru dapat menerapkan model pembelajaran group investigation untuk meningkatkan hasil belajar siswa yang maksimal.

b. Guru hendaknya lebih inovatif dalam menggunakan model pembelajaran yang sesuai dengan materi pembelajaran sehingga dapat meningkatkan minat, perhatian dan motivasi siswa untuk memahami materi yang disajikan.

\section{DAFTAR PUSTAKA}

Kunandar. 2007. Guru Profesional Implementasi KTSP dan Sukses dalam Sertifikasi Guru. Jakarta: PT Raja Grafindo Persada.

Kurniasih Imas, Sani Berlin. 2007. Ragam Pengembangan Model Pembelajaran Untuk Meningkatkan Profesionaltas Guru. Yogyakarta: Kata Pena.

Mulyatiningsih, Endang. 2013. Penelitian Tindakan Kelas (Classroom Action Research). Bandung: Alfabeta. 
Jurnal Penelitian Pendidikan Geografi Volume 3 No. 4 Oktober 2018114

Sanjaya. Wina. 2008. Perencanaan

Dan Desain Sistem

Pembelajaran. Jakarta:

Kencana.

Supardi, 2015. Penilaian Autentik.

RajaGrafindoPersada. Jakarta.

Suprihatiningrum, Jamil. 2013.

Strategi Pembelajaran:

Teoritik, Aplikasi.

Yogyakarta: Ar-Ruzz Media. 